E-ISSN : 2549-6581

DOI: 10.21776/ub.JOIM.2020.004.03.2

Artikel Hasil Penelitian

Diterima : 27 Juni 2020

Direview : 26 September 2020

Dimuat : Desember 2020 - Maret 2021

\section{OPEN ACCESS}

Journal of Issues in Midwifer

\title{
Pengaruh Pemberian Ekstrak Etanol Biji Pepaya terhadap Jumlah Sel Epitel Mukosa Tuba Fallopii Tikus Putih Betina Galur Wistar
}

\author{
Ni Luh Gede Dian Sutarini ${ }^{\left.1^{*}\right)}$, Eviana Norahmawati ${ }^{2}$, Miftahul Jannah ${ }^{3}$ \\ $\left.{ }^{1 *}\right)$ Program Studi Sarjana Kebidanan, Fakultas Kedokteran, Universitas Brawijaya Email: \\ diansutarini@gmail.com , Tlp: +6285738367579 \\ ${ }^{2}$ Departemen Patologi Anatomi, Rumah Sakit Daerah Saiful Anwar Malang Email: \\ noradwiwardoyo@gmail.com , Tlp:+6281252699680 \\ ${ }^{3}$ Program Studi Sarjana Kebidanan, Fakultas Kedokteran, Universitas Brawijaya Email: \\ jannahmiftah05@gmail.com , Tlp: +6281233902386
}

\begin{abstract}
Hormonal pills and injection are popular contraceptive method in Indonesia, with a high number of dropout rate because of the side effects. Papaya seeds are considered to have antifertility compounds as alternative contraceptives with minimum side effect. This research aims to determine the effect of papaya seed ethanol extract on the amount of mucosal epithelial cell of falopiian tube in female white rats. This research was conducted in November 2019 - January 2020 using true experimental design with Random Post Test Only Control Group Design. The research sample use 32 female white rats, divided into 4 groups: control group (without papaya seed extract), group $1(0,1 \mathrm{mg} / \mathrm{g} B W)$, group 2 $(0,2 \mathrm{mg} / \mathrm{g} \mathrm{BW})$, and group $3(0,3 \mathrm{mg} / \mathrm{g} B W)$. The treatment was given for 20 days. After treatment, sample terminated in the pro estrus phase, then histopathological examination was performed with Hematoxylin-Eosin and observed with the Olympus Dot Slide Microscope BX 51 with 400x magnification using Olyvia Application. The result showed decreased the amount of fallopian tube mucosal epithelial cells in each group as the dose increased. Conclusion of this study was the papaya seed ethanol extract has effect to decrease the structure and amount of mucosal epithelial cells of the fallopian tube with optimal doses in group 3, but statistical analysis not shown a significant difference (p>0.05).
\end{abstract}

Key words: papaya seed, mucosal epithelial tuba fallopii

\section{ABSTRAK}

Kontrasepsi hormonal pil dan suntik merupakan metode kontrasepsi populer di Indonesia, namun memiliki dropout rate tertinggi akibat efek samping penggunaannya. Biji pepaya diduga memiliki senyawa antifertilitas sebagai kontrasepsi alternatif dengan efek samping yang relatif lebih ringan. Tujuan penelitan adalah untuk mengetahui pengaruh pemberian ekstrak etanol biji pepaya terhadap jumlah sel epitel mukosa tuba fallopii tikus putih betina. Penelitian ini dilakukan pada bulan November 2019-Januari 2020 menggunakan desain true experimental dengan Randomised Post Test Only Control Group Design. Sampel penelitian menggunakan tikus putih betina sejumlah 32 ekor yang dibagi menjadi 
4 kelompok perlakuan yaitu: kelompok kontrol (tanpa pemberian ekstrak biji pepaya), perlakuan $1(0,1 \mathrm{mg} / \mathrm{g}$ BB), perlakuan $2(0,2 \mathrm{mg} / \mathrm{g} \mathrm{BB})$, dan perlakuan $3(0,3 \mathrm{mg} / \mathrm{g} \mathrm{BB})$. Perlakuan diberikan selama 20 hari, pada hari ke-21 tikus diterminasi pada fase proestrus lalu dilakukan pemeriksaan histopatologi tuba fallopii dengan pewarnaan HematoxylinEosin yang diamati dengan mikroskop Dot Slide Olympus BX 51 pembesaran 400x dengan aplikasi Olyvia. Hasil penelitian menunjukkan bahwa terdapat perbedaan struktur dan jumlah sel epitel mukosa tuba fallopii pada setiap kelompok perlakuan seiring dengan peningkatan dosis pemberian. Kesimpulan penelitian adalah ekstrak etanol biji pepaya berpengaruh menurunkan jumlah sel epitel mukosa tuba fallopii dengan dosis optimal pada kelompok perlakuan 3, namun analisis statistik belum menunjukkan perbedaan yang signifikan $(p>0.05)$.

Kata kunci: biji pepaya, sel epitel mukosa tuba fallopii

*Korespondensi: Nama Penulis. Surel: diansutarini@gmail.com

\section{PENDAHULUAN}

Kontrasepsi merupakan suatu upaya untuk mencegah terjadinya kehamilan yang dapat dilakukan dalam jangka waktu tertentu maupun ditujukan untuk mencegah kehamilan secara permanen. Upaya ini dapat dilakukan dengan berbagai cara, seperti penggunaan alat, obat, maupun usaha tertentu untuk menghambat proses fertilisasi ${ }^{(1)}$. Program penggunaan kontrasepsi di Indonesia dikenal dengan Keluarga Berencana (KB), metode KB dapat dibedakan menjadi KB modern, yaitu: sterilisasi, suntik, implant, alat kontrasepsi dalam rahim (AKDR), kondom, metode amenore laktasi (MAL), penggunaan diafragma dan kontrasepsi darurat. Sementara itu, $\mathrm{KB}$ tradisional berupa metode dengan senggama terputus dan pantang berkala $^{(2)}$.

Penggunaan kontrasepsi pil dan suntik merupakan metode yang paling populer bagi reseptor KB usia $15-49$ tahun. Metode ini terdiri dari dua jenis dengan kandungan hormon, yaitu: progesteron dan kombinasi estrogen progesteron. Meskipun banyak digunakan, metode kontrasepsi hormonal berupa pil dan suntik memiliki drop-out rate tertinggi yaitu $38,8 \%$ pada metode pil dan
$23 \%$ pada metode suntik. Hal ini terjadi karena penggunaan metode ini harus dilakukan secara berulang dan menuntut kedisiplinan akseptor. Selain itu, akseptor KB pil dan suntik mengalami keluhan lebih banyak dibandingkan metode KB lain. Keluhan yang dialami seperti: kenaikan berat badan, sakit kepala, mual, gangguan haid serta kondisi tubuh yang lemah dan letih ${ }^{(2)}$.

Sampai saat ini masih terus dikembangkan penelitian mengenai sumberdaya alam yang dapat menjadi alternatif kontrasepsi. Pemanfaatan tanaman obat dapat memberikan efek samping yang relatif lebih kecil. Selain itu, komponen tanaman yang saling mendukung dapat memberikan manfaat farmakologi lain. Salah satunya adalah penggunaan biji pada tanaman papaya ${ }^{(3)}$.

Ekstrak biji pepaya dapat menjadi alternatif kontrasepsi karena dapat menurunkan kualitas sperma tikus jantan. Kandungan utama biji pepaya yang memiliki peran sebagai senyawa antifertilitas adalah golongan saponin, tannin dan alkaloid, yang dapat mengganggu regulasi hormon reproduksi ${ }^{(4)}$. Senyawa tersebut diduga memiliki fungsi kontrasepsi karena dapat 
mengganggu

releasing hormone $(\mathrm{GnRH})$ yang berpengaruh pada konsentrasi plasma LH dan FSH. Gangguan sekresi hormon yang terjadi dapat memengaruhi struktur dan fungsi dari organ reproduksi, salah satunya tuba fallopii. Tuba fallopii memiliki fungsi transportasi dan tempat fertilisasi. Fluktuasi hormon yang terjadi selama siklus reproduksi menyebabkan perubahan pada jumlah sel epitel tuba fallopi ${ }^{(5)}$.

Sampai saat ini masih sedikit penelitian yang melihat pengaruh senyawa antifertilitas dalam biji pepaya terhadap tuba fallopii, khususnya pada sel epitel mukosa. Oleh karena itu, berdasarkan kandungan yang terdapat di dalam ekstrak biji pepaya diharapkan mampu menurunkan serta memberikan perbedaan jumlah ratarata sel epitel mukosa tuba fallopii pada tikus putih betina. Sehingga diperlukan penelitian lebih lanjut mengenai pengaruh pemberian ekstrak etanol biji pepaya terhadap jumlah sel epitel mukosa tuba fallopii tikus putih betina (Rattus norvegicus) galur wistar.

\section{METODE PENELITIAN}

\section{Rancangan Penelitian}

Rancangan penelitian ini
menggunakan desain true
experimental dengan Randomised
Post Test Only Control Group Design
menggunakan hewan coba tikus
putih.

\section{Sampel Penelitian}

Kriteria sampel hewan coba yang digunakan dalam penelitian ini adalah tikus putih (Rattus norvegicus) galur wistar jenis kelamin betina.

Perhitungan jumlah sampel terkait banyaknya ulangan dihitung menurut Frederer, sehingga diperoleh jumlah sampel penelitian pada kelompok perlakuan adalah 6 ekor, ditambahkan 2 ekor sebagai cadangan, sehingga jumlah total sampel pada penelitian ini adalah 8 ekor untuk setiap kelompok perlakuan. Jumlah seluruh sampel yang digunakan adalah 32 ekor tikus.

\section{Waktu dan Lokasi Penelitian}

Penelitian dilakukan di Laboratorium Patologi Anatomi dan Laboratorium Parasitologi FK UB pada bulan November 2019 sampai Januari 2020

\section{Pembagian Kelompok}

Kelompok kontrol (K): diberikan pakan standar per hari tanpa pemberian ekstrak etanol biji pepaya. Kelompok perlakuan 1 (P1): diberi pakan standar serta ekstrak etanol biji pepaya dosis $0,1 \mathrm{mg} / \mathrm{g}$ BB $1 \mathrm{kali}$ per hari. Kelompok perlakuan 2 (P2): diberi pakan standar serta ekstrak etanol biji pepaya dengan dosis 0,2 $\mathrm{mg} / \mathrm{g}$ BB 1 kali per hari Kelompok perlakuan 3 (P3): diberi pakan standar serta ekstrak etanol biji pepaya dengan dosis $0,3 \mathrm{mg} / \mathrm{g}$ BB 1 kali per hari

\section{Variabel Penelitian}

Variabel Independen: pemberian esktrak etanol biji pepaya dengan dosis $0,1 \mathrm{mg} / \mathrm{g} \mathrm{BB}, 0,2 \mathrm{mg} / \mathrm{g} B B$, dan $0.3 \mathrm{mg} / \mathrm{g}$ BB. Variabel Dependen: jumlah sel epitel mukosa tuba fallopii. Variabel Terkendali: galur tikus, jenis kelamin tikus, berat badan tikus, pakan dan kondisi lingkungan kandang

\section{Prosedur Penelitian}

Hewan coba diaklimatisasi selama 7 hari dan dilakukan pengecekan keteraturan siklus estrus. Perlakuan mulai diberikan 
saat hewan coba berada pada fase diestrus hingga 20 hari masa perlakuan. Hari ke-21 dilakukan pengambilan hapusan vagina pada hewan coba, jika hewan coba berada pada fase proestrus maka dilakukan terminasi dengan dislokasi leher untuk diambil organ tuba fallopii kiri dan kanan. Kemudian dibuat sediaan histopatologi pewarnaan menggunakan dengan mikroskop Dot Slide Olympus $B X 51$ dan dilakukan pengamatan jumlah sel dengan aplikasi Olyvia pada 8 lapang pandang dan pembesaran 400x.

\section{Teknik Analisis Data}

Normalitas data diuji dengan Shapiro Wilk, homogentitas data diuji dengan Levene Test, lalu dilanjutkan uji beda dengan One Way ANOVA dan uji beda antar kelompokk dengan Post Hoc Tukey HSD.

\section{HASIL PENELITIAN}

\section{Hasil Pengamatan Sel Epitel Mukosa Tuba Fallopii \\ Hasil pengamatan sel epitel mukosa tuba fallopii dapat dilihat pada gambar berikut}
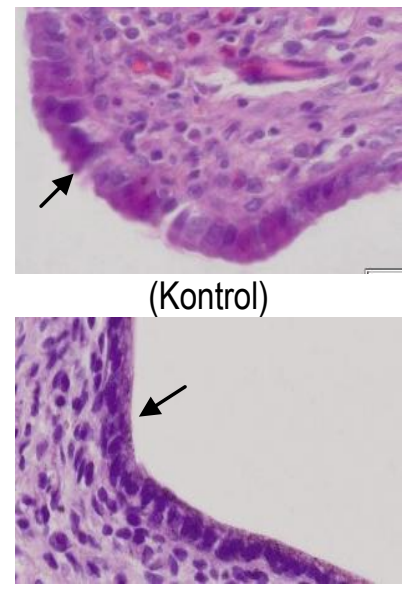

(Perlakuan 2)

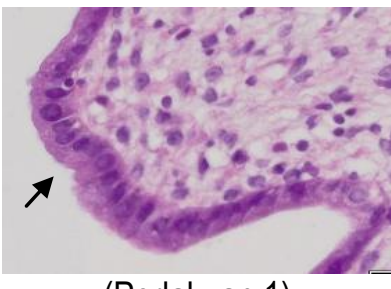

(Perlakuan 1)

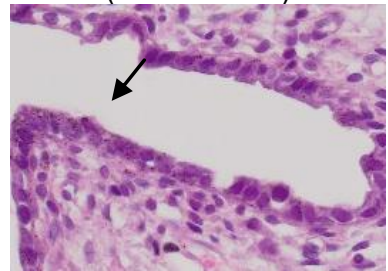

(Perlakuan 3)

Gambar histopatologi kelompok K, P1, P2 dan P3, Tanda panah menunjukkan sel epitel mukosa tuba fallopii (Hematoxylin-Eosin, 400x)

\section{Gambar 1. Pengamatan Histopatologi Sel Epitel Mukosa Tuba Fallopii}

Berdasarkan hasil pengamatan, pada gambar sel epitel mukosa tuba fallopii terlihat adanya perbedaan antar kelompok perlakuan, kelompok kontrol (K) menunjukkan barisan sel epitel kolumnar yang tinggi, rapat dan terdapat silia. Perlakuan 1 (P1) menunjukkan barisan sel epitel kolumnar yang tinggi dan terdapat silia. Perlakuan 2 (P2) menunjukkan barisan sel epitel kolumnar yang tinggi dan tidak terdapat silia.
Perlakuan 3 (P3) menunjukkan tanda-tanda terjadinya apoptosis sel, yang terlihat dari barisan sel epitel kolumnar yang pendek, berjarak dan tidak terdapat silia

\section{Hasil Perhitungan Sel Epitel Mukosa Tuba Fallopii}

Hasil perhitungan jumlah ratarata dari sel epitel mukosa tuba fallopii dapat dilihat pada tabel dibawah ini 
Tabel 1. Rata-Rata Jumlah Sel Epitel Mukosa Tuba Fallopii

\begin{tabular}{lcccc}
\hline & K & Perlakuan 1 (P1) & Perlakuan 2 (P2) & Perlakuan 3 (P3) \\
\hline Rata-rata & 24.33 & 23.44 & 19.50 & 19.10 \\
\hline $\begin{array}{l}\text { Standar } \\
\text { Deviasi }\end{array}$ & \pm 6.06 & \pm 4.18 & \pm 3.57 & \pm 6.56 \\
\hline
\end{tabular}

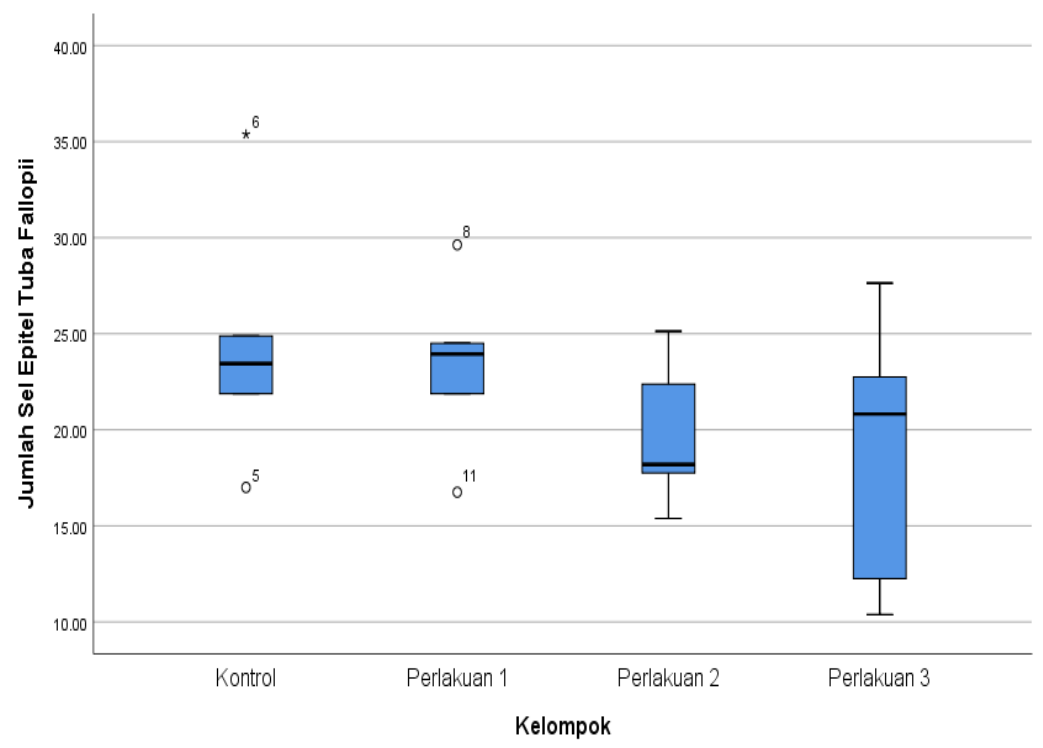

Gambar 2. Diagram Boxplot Jumlah Sel Epitel Mukosa Tuba Fallopii

Jumlah rata-rata dari sel epitel mukosa tuba fallopii kelompok kontrol (K) lebih tinggi dibandingkan dengan jumlah rata-rata sel epitel kelompok perlakuan, yaitu 24.33 \pm 6.06 ; perlakuan $1(\mathrm{P} 1)$ dengan rata-rata sel sejumlah 23.44 \pm 4.18 ; memiliki hasil yang lebih rendah dibandingkan dengan rata-rata sel kelompok kontrol namun memiliki hasil lebih tinggi dibandingkan kelompok perlakuan lain. Perlakuan 2 (P2) dengan ratarata sel sejumlah $19.50 \pm 3.57$; memiliki hasil yang lebih rendah jika dibandingkan dengan rata-rata sel kelompok kontrol dan P1, namun lebih tinggi dibandingkan P3. Perlakuan 3 (P3) dengan rata-rata sel sejumlah $19.10 \pm 6.56$; merupakan kelompok dengan hasil rata-rata terendah dibandingkan kelompok kontrol, P1 dan P2.

\section{Hasil Analisis Data}

Analisis data dengan uji normalitas menggunakan Shapiro Wilk menghasilkan nilai $p>0.05$ yang menunjukkan bahwa seluruh kelompok memiliki sebaran data normal. Hasil uji homogenitas dengan uji Levene Test menunjukkan $\mathrm{p}>$ 0.05 yang berarti variansi data telah homogen. Uji beda dengan One Way ANOVA memberikan hasil sebagai beri

Tabel 2. Uji One Way ANOVA

\begin{tabular}{lllllc}
\hline & Sum of Squares & $d f$ & Mean Square & Sig. & Ket \\
\hline Between Groups & 128.926 & 3 & 42.975 & 0.229 & Tidak Signifikan \\
\hline Within Groups & 549.702 & 20 & 27.485 & & \\
\hline Total & 678.627 & 23 & & & \\
\hline
\end{tabular}


Uji beda dengan One Way ANOVA menunjukkan hasil $p>0.05$ yang berarti pemberian ekstrak etanol biji pepaya tidak memiliki pengaruh yang signifikan terhadap perbedaan rata-rata jumlah sel epitel mukosa tuba fallopii. Selanjutnya dilakukan uji perbedaan antar kelompok dengan Post Hoc TukeyHSD.

Tabel 3. Uji Post Hoc Tukey HSD

Multiple Comparison

Tukey HSD

\begin{tabular}{|c|c|c|c|c|}
\hline & & $\begin{array}{c}\text { Mean Difference } \\
(I-J)\end{array}$ & Sig. & Ket \\
\hline \multirow{3}{*}{ K } & $\mathrm{P} 1$ & .89667 & .991 & \\
\hline & P2 & 4.83333 & .403 & \\
\hline & P3 & 5.23000 & .336 & Mendekati Signifikan \\
\hline & $\mathrm{K}$ & -.89667 & .991 & \\
\hline \multirow[t]{2}{*}{$\mathrm{P} 1$} & P2 & 3.93667 & .573 & \\
\hline & P3 & 4.33333 & .495 & \\
\hline \multirow{3}{*}{ P2 } & $\mathrm{K}$ & -4.83333 & .403 & \\
\hline & P1 & -3.93667 & .573 & \\
\hline & P3 & .39667 & .999 & \\
\hline & $\mathrm{K}$ & -5.23000 & .336 & Mendekati Signifikan \\
\hline \multirow[t]{2}{*}{ P3 } & P1 & -4.33333 & .495 & \\
\hline & P2 & -.39667 & .999 & \\
\hline
\end{tabular}

Berdasarkan hasil uji beda antar kelompok dengan Post Hoc Tukey HSD bahwa kelompok kontrol, perlakuan 1 (P1), perlakuan 2 (P2), perlakuan 3 (P3) menunjukkan hasil $p$ $>0.05$ yang berarti tidak terdapat hubungan signifikan. Namun terdapat kelompok dengan nilai paling mendekati signifikan dibandingkan kelompok perlakuan lain dengan nilai $\mathrm{p}=0.336$ yaitu kelompok kontrol $(\mathrm{K})$ dan kelompok perlakuan 3 (P3).

$$
\text { Hasil analisis data }
$$
menunjukkan pemberian ekstrak etanol biji pepaya menurunkan ratarata jumlah sel epitel mukosa tuba fallopii namun tidak menunjukkan adanya perbedaan yang signifikan.

\section{PEMBAHASAN}

\section{Pengaruh Pemberian Ekstrak Etanol Biji Pepaya terhadap Sel Epitel Mukosa Tuba Fallopi}

Berdasarkan pengamatan histopatologi terdapat adanya perbedaan morfologi dan jumlah sel pada kelompok kontrol dan kelompok perlakuan. Terjadi penurunan jumlah sel serta penurunan tinggi sel epitel kolumnar seiring dengan peningkatan dosis perlakuan. Perbedaan morfologi yang terlihat pada kelompok kontrol dan kelompok perlakuan adalah tinggi sel epitel kolumnar dan adanya silia sel, perbedaan ini dapat terjadi akibat adanya senyawa kimia dalam biji pepaya yaitu golongan fenol, alkaloid, triterpenoid dan saponin ${ }^{(6)}$.

Senyawa kimia dalam biji pepaya tersebut diduga berperan sebagai senyawa yang memberikan efek antifertilitas. Senyawa saponin bekerja pada aksis hipotalamushipofisis-gonad yang dapat mengganggu sekresi $\mathrm{GnRH}$ di hipotalamus yang menyebabkan penurunan sekresi FSH dan LH sehingga sintesis hormon reproduksi di ovarium terganggu ${ }^{(7)}$. Adanya 
senyawa alkaloid yang terkandung dalam biji pepaya juga memiliki pengaruh terhadap ganguan konsentrasi plasma pada $\mathrm{FSH}, \mathrm{LH}$ dan estradiol ${ }^{(5)}$.

Penurunan sekresi FSH akibat aktivitas senyawa antifertilitas ekstrak etanol biji pepaya menyebabkan adanya perubahan struktur dari sel granulosa di ovarium yang meningkatkan resiko atresia folikel sebelum ovulasi. Hal ini menyebabkan terjadinya penurunan sekresi hormon estrogen akibat terganggunya proses maturasi folikel di ovarium yang akan mengganggu proses ovulasi. Kadar hormon estrogen juga berpengaruh terhadap aktivitas struktural dan fungsional dari organ reproduksi sekunder yang sensitif terhadap fluktuasi hormon estrogen saat ovulasi, salah satunya adalah sel epitel mukosa tuba fallopii.

Bagian sel epitel tuba fallopii terdiri dari sel siliaris dan sel sekretorik yang memiliki aktivitas struktural dan fungsional seiring dengan fluktuasi hormon steroid dalam siklus reproduksi yaitu aktivitas hormon estrogen dan progesteron. Proliferasi sel epitel mukosa pada organ tuba fallopii ditandai dengan adanya peningkatan aktivitas sel siliaris dan sekretorik yang dapat berupa penambahan jumlah sel, perubahan ukuran dan tinggi sel epitel, serta adanya silia sel. Perubahan ini sangat dipengaruhi oleh fluktuasi hormon yang berubah seiring dengan meningkatnya hormon estrogen menjelang ovulasi. Fluktuasi ini akan terus berlangsung hingga mencapai puncaknya pada saat ovulasi dengan kadar estrogen dominan. Sehingga jika ditemukan adanya senyawa yang mengganggu regulasi $\mathrm{FSH}$ hingga menghambat sekresi hormon estrogen pada masa ovulasi, hal tersebut akan memengaruhi proliferasi sel epitel mukosa tuba fallopii terhadap struktur dan fungsi sel epitel siliaris dan sekretorik dalam siklus reproduksi ${ }^{(8)}$.

\section{Pengaruh Ekstrak Etanol Biji Pepaya terhadap Rata-rata Jumlah Sel Epitel Mukosa Tuba Fallopii}

Rata-rata jumlah sel epitel mukosa pada organ tuba fallopii mengalami penurunan seiring dengan peningkatan dosis pemberian ekstrak etanol biji pepaya. Kelompok kontrol (K) memiliki hasil rata-rata tertinggi, diikuti dengan perlakuan 1 (P1), perlakuan 2 (P2) dan perlakuan 3 (P3), dengan rata-rata jumlah sel terendah pada kelompok perlakuan 3 (P3).

Terminasi tikus dilakukan pada saat tikus memasuki fase proestrus, sehingga pengamatan dan perhitungan rata-rata jumlah sel epitel mukosa dapat menggambarkan pengaruh dari ekstrak etanol biji pepaya terhadap aktivitas epitel tuba fallopii sebelum masa ovulasi. Pada kondisi normal tanpa perlakuan, sel epitel mukosa tuba fallopii akan berproliferasi seiring dengan peningkatan hormon estrogen menjelang ovulasi. Namun kelompok yang diberi perlakuan dengan ekstrak etanol biji pepaya akan mengalami gangguan sekresi hormon jalur hipotalamus-hipofisis-gonad sehingga menyebabkan gangguan sekresi FSH. Gangguan sekresi hormon dari hipofisis akan berdampak pada gangguan maturasi folikel ovarium sehingga terjadi gangguan sekresi hormon estrogen dari ovarium untuk ovulasi.

Hal tersebut didukung oleh hasil penelitian Puspitasari tahun 2014 yang menunjukkan adanya perbedaan signifikan dari pemberian ekstrak etanol biji pepaya terhadap kualitas dan jumlah sel telur pada 
hewan coba tikus ${ }^{(9)}$. Penelitian Punitha tahun 2015 juga menyebutkan bahwa senyawa antifertilitas dalam ekstrak etanol biji pepaya dapat memberikan efek melalui poros hipofisis gonad yang mengakibatkan gangguan sekresi hormon estrogen sehingga berdampak pada aktivitas struktural dan fungsional organ reproduksi selama siklus reproduksi ${ }^{(10)}$.

Hormon estrogen yang di sekresi oleh hipofisis dan ovarium akan berikatan dengan reseptor estrogen di tuba fallopii, lalu terjadi perpindahan dari reseptor ke inti sel yang kemudian berikatan dengan Estrogen Reseptor Element (ERE) di inti sel. Setelah berikatan dengan ERE terjadi ikatan dengan koaktivator, lalu proses transkripsi dan translasi mengubah ekspresi gen yang kemudian menghasilkan suatu protein spesifik. Protein tersebut akan menentukan manifestasi struktur dan fungsi dari tuba fallopii, salah satunya adalah sel epitel mukosa. Sehingga sel epitel di mukosa tuba fallopii akan bermanifestasi sesuai dengan kadar estrogen yang diterima oleh reseptornya ${ }^{(11)}$. Oleh karena itu, proliferasi sel epitel mukosa di tuba fallopii dapat diamati melalui rata-rata jumlah serta morfologi sel pada setiap kelompok. Hasil menunjukkan bahwa peningkatan dosis ekstrak etanol biji pepaya memberikan pengaruh pada penurunan rata-rata jumlah sel epitel di tuba fallopii. Pengaruh tersebut terjadi karena adanya senyawa tanin, alkaloid dan saponin yang menghambat sekresi hormon estrogen pada jalur hipotalamus-hipofisis-gonad yang menyebabkan perubahan morfologi dan penurunan jumlah sel epitel di tuba fallopii.

$$
\text { Meskipun terdapat }
$$

penurunan rata-rata jumlah sel pada kelompok kontrol dan kelompok perlakuan, analisis uji beda One Way ANOVA menunjukkan hasil 0.229 ( $p>0.05$ ) yang berarti pemberian ekstrak etanol biji pepaya tidak memberikan pengaruh yang signifikan.

Hal ini dapat terjadi karena di dalam senyawa fitokimia ekstrak etanol biji pepaya terdapat senyawa triterpenoid, tannin, phenol, saponin, dan alkaloid yang didalamnya juga terdapat flavonoid. Menurut penelitian Salim pada tahun 2018 kandungan saponin dan tannin memiliki persentase lebih tinggi dibandingkan senyawa flavonoid, persentase kandungan flavonoid dalam ekstrak etanol biji pepaya memiliki kadar terendah dibandingkan 3 senyawa tersebut. Meskipun memiliki kadar yang relatif rendah, adanya senyawa flavonoid dapat membantu peningkatan proliferasi sel pada jaringan $^{(12)}$. Selain itu, kandungan flavonoid juga memiliki aktivitas estrogenik dan anti estrogenik secara dose dependent. Hal ini mungkin terjadi karena beberapa senyawa dengan estogen dose dependent mampu menstimulasi pertumbuhan sel yang berikatan dengan reseptor estrogen dalam konsentrasi rendah, namun dalam konsentrasi tinggi memberikan efek kebalikannya karena menurunkan ekskresi reseptor estrogen atau menghambat tirosin kinase $^{(13)}$.

\section{Dosis Optimal yang Berpengaruh Terhadap Jumlah Sel Epitel Mukosa Tuba Fallopii}

Hasil

pengamatan menunjukkan adanya perbedaan jumlah serta morfologi sel epitel di mukosa tuba fallopi. Perbedaan tersebut semakin terlihat dari peningkatan dosis yang diberikan. Semakin tinggi dosis yang digunakan, 
maka struktur sel epitel kolumnar terlihat merenggang dan memendek diikuti dengan hilangnya silia sel. Hal tersebut juga terjadi pada penurunan rata-rata jumlah sel, semakin tinggi dosis yang diberikan maka jumlah rata-rata sel semakin menurun. Berdasarkan hasil penelitian, pemberian ekstrak etanol biji pepaya pada kelompok perlakuan 3 (P3) dengan dosis $0,3 \mathrm{mg} / \mathrm{g} \quad \mathrm{BB}$ merupakan kelompok dengan dosis paling berpengaruh terhadap morfologi dan rata-rata jumlah sel. Namun belum menunjukkan perbedaan yang signifikan dari hasil analisis statistik menggunakan uji One Way ANOVA dan Post Hoc Tukey HSD.

\section{SIMPULAN}

Kesimpulan penelitian ini adalah pemberian ekstrak etanol biji pepaya berpengaruh menurunkan jumlah sel epitel mukosa tuba fallopii tikus putih betina dalam tiga dosis bertingkat dengan dosis optimal pada pemberian $0,3 \mathrm{mg} / \mathrm{Kg}$ BB namun analisis statistik belum menunjukkan perbedaan yang signifikan.

Saran penelitian ini adalah perlu dilakukan penelitian lanjutan untuk mencari dosis ekstrak etanol biji pepaya yang mempu memberikan pengaruh signifikan terhadpa variabel sel epitel mukosa tuba fallopii tikus putih betina.

\section{DAFTAR PUSTAKA}

1. Dabhadkar, D. K., Thakare, V. G., Zade, V. S., Charjan, A. P., Dhore, M. M., \& Deosthale, S. M. 2015. Review on some ethnomedicinal plants having antifertility activity in female albino rats. International Res. Journal of Science \& Engineering. 3(2): 4146.

2. Kemenkes RI. 2013. Situasi Keluaga
Berencana di Indonesia. Buletin Jendela Data dan Informasi Kesehatan.

3. Katno dan S. Pramono. 2010. Tingkat Manfaat dan Keamanan Tanaman obat dan Obat Tradisional. Balai Penelitian Tanaman Obat Tawangmangu, Fakultas Farmasi, UGM. Yogyakarta

4. Setyowati, E.A.W., D.R.S. Ariani, Ashadi, B. Mulyani, A. Hidayat. 2015. Aktivitas Antifertilitas Kontrasepsi Dari Kulit Durian (Durio zibethinus Murr.) Varietas Petruk. Program Studi Pendidikan Kimia Jurusan FMIPA FKIP UNS, Surakarta

5. Ankush Raj, Singh, A., Sharma, A., Singh, N., Kumar, P., \& Bhatia, V. 2011. Antifertility activity of medicinal plants on reproductive system of female rat. International Journal of Bio-Engineering Sciences \& Technology, 2(3).

6. Paramesti, Niken N. 2014. Efektivitas Ekstrak Biji Pepaya (Carica papaya L.) Sebagai Antibakteri Terhadap Bakteri Escherichia coli. Disertasi Universitas Islam Negeri Syarif Hidayatullah.

7. Udoh, F. V., \& Udoh, P. B. 2005. Hepatotoxicity of the Methanol Extract of Carica papaya (Paw-Paw) Seeds in Wistar Rats. Pharmaceutical biology, 43(4), 349-352.

8. Cui, D., Daley, W. P., Fratkin, J. D., Haines, D. E., Lynch, J. C., Naftel, J. P., \& Yang, G. 2011. Atlas of histology: with functional and clinical correlations.

Wolters Kluwer/Lippincott Williams \& Wilkins. $\mathrm{Hal}$ 461-487

9. Puspitasari, Y., Suhita, B. M., \& Srianto, P. (2014). Pemberian Ekstrak Etanol Biji Pepaya (Carica papaya) pada Tikus Betina (Rattus Novergicus) Sebagai Alternatif Bahan 
Antifertilitas

Terhadap

Folikulogenesis, Kualitas Sel Telur dan Angka Fertilisasi. Media Kedokteran Hewan, 30(1), 61-66.

10. Punitha, N., N. Shettu and R. Saravanan. 2015. Effect of Semi-Ripe Carica papaya Fruit Extracts on the Reproductive Structures in Female Albino Rats a Histological Study. International Journal of Current Research in Life Sciences. 4(6)

11. Ikawati, Z. 2008. Pengantar Farmakologi Molekuler. Gadjah Mada University Pres. Yogyakarta

12. Salim, A. N., Sumardianto, S., \& Amalia, U. 2011. Efektivitas Serbuk
Simplisia Biji Pepaya sebagai Antibakteri pada Udang Putih (Penaeus merguensis) Selama Penyimpanan Dingin. Jurnal Pengolahan Hasil Perikanan Indonesia, 21(2), 188-198.

13. Han, D. H., Denison, M. S., Tachibana, H., \& Yamda, K. 2002. Relationship between estrogen receptor-binding and estrogenic activities of environmental estrogens and suppression by flavonoids. Bioscience, biotechnology, and biochemistry, 66(7), 1479-1487. 